\title{
國际科学界动态
}

\section{世界科学工作者协会执行理事會就 核子武器所帶來的危險發表声明}

世界科学工作者协会同許多其他組絨和許多各別的科学工作者（他括一些發言極有

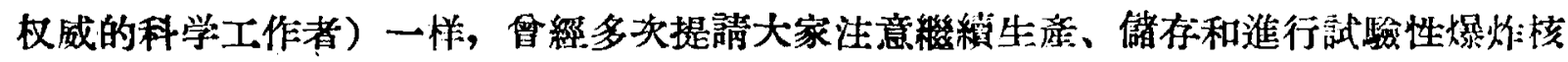
子武器所帶隶的危險。

它認为这种危险只有由大國締結一項全面裁苹协議和宣布这种武器为非法才能消 减。世界科学工作者协会执行理事会第十六届会議因此欢迎联合國大会裁军委員会繼結 淮行討論。它要求所有参加討論的國家作一次最大的努力, 就釈面未决的問題达成协議,

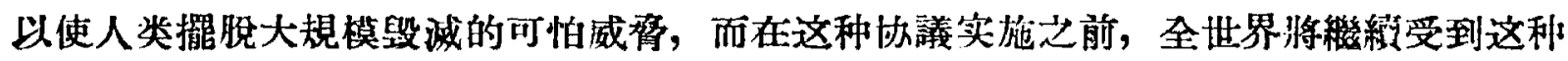
威捐。

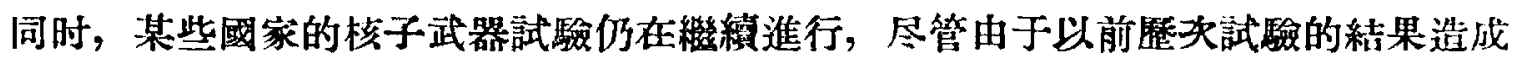

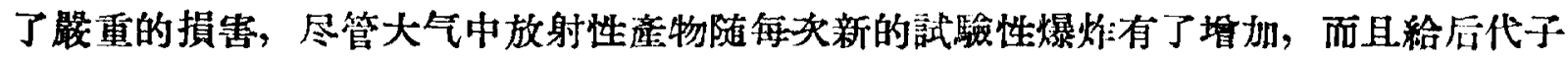

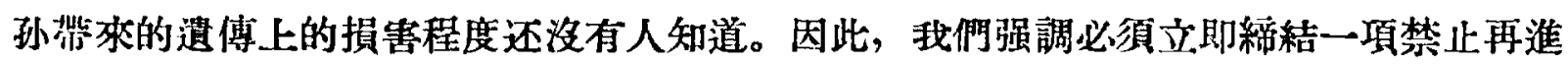
行一切原子和热核子武器試驗的國际公約。我們坚决認为, 立即禁止核子武器試驗是完 全切实可行的, 因为測查这和武器的試驗并不存在技盛上的困难。

在目前筑重的局势下, 我們号召一切國家中的科学家們以更大的决心大声疾呼反对

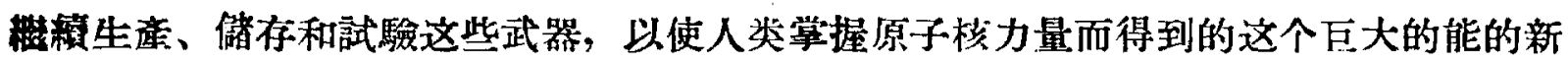

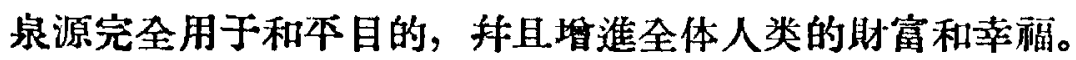

